\title{
ВЕРБАЛІЗАЦІЯ КОНЦЕПТУ СВЯЩЕННОСЛУЖИТЕЛЬ В УКРАЇНСЬКИХ ПАРЕМІЯХ
}

\author{
НАТАЛІЯ ПІДДУБНА \\ Харківський національний педагогічний університет імені Г. С. Сковороди, \\ Харків - Україна
WERBALIZACJA KONCEPTU „DUCHOWNY” W UKRAINSSKICH PAREMIACH \\ NATALIA PIDDUBNA \\ Charkowski Narodowy Uniwersytet Pedagogiczny im. H. Skoworody, \\ Charków - Ukraina
}

STRESZCZENIE. Artykuł analizuje konkretne werbalizacje konceptu „duchowny” $\mathrm{w}$ ukraińskich paremiach odnotowanych w zbiorach pochodzących z różnych okresów. Wnioski płynące z powyższej analizy potwierdzają ironiczny obraz kleru różnych wyznań, a także ogólną tendencję do negatywnych konotacji konceptu „duchowny”.

\section{VERBALIZATION OF CONCEPT CLERIC IN UKRAINIAN PAREMIAS}

\section{NATALIA PIDDUBNA}

H. S. Skovoroda Kharkiv National Pedagogical University, Kharkiv — Ukraine

ABSTRACT. This article analyzes the specific verbalization of the concept CLERIC in Ukrainian paremias recorded in collections issued at different times. It focuses on the means of creating the ironic image of priests of different religious affiliations, a general trend of negative connotations of clergymen.

2 агальновизнано, що дослідження пареміологічного фонду кожної нації це ключ до декодування багатовікового досвіду народу, його світосприйняття. М. Алефіренко справедливо зазначає: „Вивчення прислів’їв і приказок, які відображають уявлення про світ усередині окремої національно-культурної традиції, що формує свій склад словника й визначає особливості текстової організації, дасть змогу виявити специфіку сприйняття й пізнання світу різними народами, характер відображення й членування світу мовою певного етносу"1.

Паремії - це те унікальне надбання лінгвокультури, що відбиває фактично всі аспекти життєдіяльності людини. Винятком не є і концептосфера „Релігія”, що в останні десятиліття позначена посиленням уваги з боку науковців, зокрема лінгвістів. Так питанням відбиття релігійної картини світу в українській пареміології присвячені наукові розвідки низки дослідників, зокрема Л. Савченко аналізує ті прислів'я та фразеологізми, походження яких пов’язується з об-

${ }^{1}$ Н. Ф. Але фире нко, Язык, познание и культура: Когнитивно-семиологическая синергетика слова, Волгоград 2006, с. 117. 
рядами, традиціями й віруваннями різдвяно-новорічного циклу ${ }^{2}$, Т. Свердан досліджує вплив християнської моралі на світогляд українців і вербалізацію цього впливу в українських прислів'ях (на матеріалі, зібраному І. Югасевичем) ${ }^{3}$, Н. Ковальська характеризує зміни релігійного світобачення та їхню фіксацію в українських пареміях ${ }^{4}$. Однак попри наявність таких розвідок на сьогодні ще відчувається брак спеціальних досліджень, де б предметом аналізу була концептуалізація окремих фрагментів релігійної картини світу, зокрема концепту „священнослужитель”, засобами українських паремій.

Отже, авторка цієї наукової студії має на меті з'ясувати особливості вербалізації мовного образу священнослужителя в українських пареміях. Наголосимо, що цей вагомий складник концептосфери „Релігія” не був предметом спеціальних монографічних праць, дисертаційних робіт, за винятком кількох, передусім це праця С. Біблої5, виконана на матеріалі назв церковних чинів і посад, де проаналізовано склад, джерела й шляхи формування церковної термінології, та фундаментальна наукова розвідка А. Ковтун ${ }^{6}$, у якій здійснено аналіз модифікації семантики найменування духовних осіб у художній прозі ХХ ст.

Відомо, що в пареміях як одиницях комунікативного характеру не лише констатується певний стан речей чи людських рис, а й дається їм оцінка. Отже, паремії містять оцінку змісту інформації, в основі чого лежать емоційні чинники.

Постаті священнослужителів і членів їхніх сімей, а також ченців традиційно перебувають у центрі уваги парафіян, що, безумовно, відбито в кількості й, так би мовити, якості паремій, у яких так чи так ідеться про релігійну особу, напр., у Галицько-руських народних приповідках І. Франка зафіксовано 79 паремій 3 лексемою $\mathrm{nin}, 10-3$ лексемою попадя, 6 - ксьондз, 6 - владика, 2 - 3 лексемою ігумен, по 1 паремії з лексичними компонентами панотець, єрей, біскуn.

Як бачимо, переважна більшість паремій на позначення узагальненого священно- і церковнослужителя містить лексему nin, яка $\epsilon$ народною негативно конотованою назвою священика, що, як і деякі інші найменування (церква, дячиха, попик і под.), виражають мінімальний ступінь християнсько-релігійної оцінки, де „відображається становлення духовності людини, прагнення до удосконалення душі, праведного життя (оцінка релігійних, культових споруд, служителів церкви, предметів церковних обрядів тощо)"7. Виразно помітна ця конотація в процесі порівняння зі стилістично нейтральними запозиченими канонічними термінами священик, пресвітер, ієрей або й народними позитивно конотованими отець, панотецьь, батюшка.

2 Л. С ав ч е н ко, Інтерпретація сакральних мікрокониептів різдвяно-новорічного комплексу обрядодій i їх відображення у фразеологізмах $і$ пареміях, [в:] „Науковий вісник Чернівецького національного університету імені Юрія Федьковича": Слов'янська філологія Чернівці 2010, вип. 506-508, с. 130-136.

${ }^{3}$ Т. С ве рдан, Християнська мораль $і$ народна філософія у прислів'ях, зібраних Іваном Югасевичем, [в:] "Науковий вісник Чернівецького національного університету імені Юрія Федьковича”: Слов'янська філологія Чернівці 2010, вип. 509-511, с. 121-126.

${ }^{4} \mathrm{H}$. А. Ков в ль с ь ка, Зміни релігійного світобачення в украӥнських пареміях (лексема Бог та їі семантичні синоніми), [в:] „Лінгвістичні дослідження”, за ред. Л. А. Ли с иченко, Харків 2007, c. 9-13.

${ }^{5}$ С. В. Бібла, Склад, джерела і шляхи формування украӥнської иерковної термінології (назви иерковних чинів та посад), Автореф. дис. канд. філол. наук, Київ 1997.

${ }^{6}$ А. А. Ковтун, Інноваційні процеси в украӥнській иерковно-релігійній лексииі (на матеріалі художньої прози XX ст.), Дис. канд. філол. наук, Чернівці 2006, с. 274.

7 Т. Косм еда, Аксіологічні аспекти прагмалінгвістики: формування і розвиток категорії оцінки, Львів 2000, с. 99. 
Таким чином, можемо розмірковувати про те, що в українських пареміях образ священика омовлюється дещо критично, а паремії здебільшого репрезентують гумористичну, іронічну, а то й саркастичну тональність, відповідний колорит. Т. Свердан із цього приводу зауважує: „Але українці не були б українцями, якби часом не пожартували навіть на теми сакрального (втім, на такі теми жартують і представники інших народів, більше того, деякі дослідники виокремлюють жарти 3 „набоженською” тематикою як окремий вид ідіом). У цьому разі „спрацьовує” народна філософія земного, практичного буття, що не завжди збігається з християнськими настановами життя духовного, небесного (до слова, це зовсім не означає, що християнську мораль відкинуто)"», напр., іронічно звучать вирази, зафіксовані І. Франком: Піп - Дух святий при нас!, де укладач подає такий коментар: „говорять з острахом, як про злого духа, розуміється іронічно"; Піп не Бог, поліція не війт „Говорять кепкуючи” (ГРНП, т. 2, с. 723).

Традиційно автори паремій менше кепкують із зовнішності священика. Так, згідно 3 авторською картотекою, вона іронічно відбита лише в одній паремії, зафіксованій I. Франком: Піп як бобовий сніп — „Кепкують $з$ попа малого росту” (ГРНП, т. 2, с. 723). Значно частіше у фокусі уваги народних дотепників внутрішні якості священика, риси його характеру, переважно негативні, насамперед такі, як честолюбство (Аби лиш два попи на світі жило, то ще б їм затісно було), нещирість, дволикість (Не вір попові, як nсові; Піп з Богом говорить, а на чорта дивиться; Убрався піп у ризу, а чорт в рядно, і говорять одно; Піп гроші збирає, а чорт калитку шиє; Сюди хрестом, а туди хвостом; Піп каже: „, Слухай моӥх слів, а не пильнуй моїх діл”; Роби теє, щзо піп каже, а не роби теє, щзо піп робить; Читає: „Да буде воля Твоя”, а дума: „Якби моя” та ін.); жадібність (Не годен попа наситити, як дірявого міха; У попа здачі, а в кравия остачі не питай; Краще з ведмедем борюкатися, як з попом боргуватися; Попу оддай діжу з тістом, то він тісто вибере і тобі очі видере та ін.); серебролюбство (За гроші піп і чорта поцілує; Піп Наум навів бабу на ум: баба порося продала, а гроші попові дала; У попа завжди долоня свербить; У попа крам - пекло й рай, щзо хочеш, те й вибирай та ін.); черевоугодництво (До роботи поп, а до їла хлоп; У попа дна нема; Знехотя піп і порося з їв; Попа одним обідом не нагодуєш; Тікайте, кури, піп іде! та ін.).

Значна частина наведених паремій позначена вживанням лексики, що належить до різних - часто протилежних - ЛСГ (nin - nec, Бог - чорm, nin - чорm, nin - ведмідь та ін.), що уможливлює посилення експресивності всього виразу. Із цього приводу В. Чабаненко зазначає: „Поєднання в складі одного структурного цілого (речення, словосполучення) різносистемних (різностильових) елементів і контрастування їх створюють експресію потужної сили й виконують важливі стилістичні функції. Тому цілком природно, що міжстильові зіткнення найчастіше практикуються в тих мовних різновидах (підсистемах) і жанрах, де пошук експресивності є дуже інтенсивним (у художньо-белетристичних жанpax, публіцистиці та в усному мовленні). Як правило, вони використовуються для створення гумористичних, іронічних та інших ефектів"10.

\footnotetext{
${ }^{8}$ Т. С ве рдан, зазн. джерело, с. 123.
}

9 I. Франко, Галицько-руські народні приповідки, у 3 т., Львів 2006, т. 2, с. 723 — далі поклик на це джерело подаємо в круглих дужках у тексті статті з використанням скорочення ГРНП, після якого подаємо вказівку на том і конкретну сторінку.

10 В. А. Чабаненко, Стилістика експресивних засобів украӥнськой мови, Запоріжжя 2002, c. 16 . 
Прикметно, що в українських прислів'ях відображене іронічне ставлення не лише до православних чи греко-католицьких, а й до римо-католицьких священнослужителів, чиї моральні якості теж піддаються сумнівам: Bci попи одним миром мазані; Один чорт піп, щзо стрижений, щз кудлатий, - усі люблять брати; Віри різні, а попи однакові; Чи піп, чи ксьондз, чи яка нечиста сила, - та все з хлопа тягне ${ }^{11}$; Попівське око, ксьондзівське горло, - щзо бачило, то б жерло (УНПП, с. 23); Ци піп, ции ксьондз, цчи яка така стила мама, тай все з хлопа тягни - нарікання „на здирства руських і латинських попів. „Стила мама” - нечиста сила” (ГРНП, т. 2, с. 725.) Католицький священик, як і православний, зрештою, як і кожна інша звичайна людина, може бути грішним але, очевидно, що гріховність духівника за народними уявленнями ще більш помітна, що й фіксує I. Франко, напр.: Христос тя скаре крім святого пліша! Мовила баба ксьондзови — ,у латинських ксьондзів на тімені єсть місце виголене, що зветься тонзурою. У погляді тої жінки, що говорила сі слова, у того ксьондза все тіло було грішне, крім того святого пліша" (ГРНП, т. 3, с. 372). Наявність у Галицько-руських народних приповідках значної частини 3 наведених паремій доводить, що негативна конотація образу священика не $\epsilon$ виключно вигадкою радянської атеїстичної пропаганди, а коріниться в народному світосприйнятті з більш давнього часу.

На однаково критичне ставлення до священиків незалежно від їхньої конфесійної приналежності вказує й те, що в багатьох пареміях лексичне наповнення відрізняється лише вживанням лексеми nin чи ксьондз, порівн.: Ксьондз два рази казаньи не каже (ГРНП, т. 2, с. 428) - Піп два рази казаня не каже (ГРНП, т. 2, с. 722); Піп з дяком, воба вовчі горла — „Оба ненаситні” (ГРНП, т. 2, с. 723); Ксьондз і дяк, воба вовчі горла — „один і другий ніколи не насититься” (ГРНП, т. 2, с. 428). Очевидно, в народному сприйнятті моральні якості і попа, і ксьондза не багато чим відрізняються, питання лише в частотності вживання лексеми nin, що, як видається, в пареміях виконує функцію гіпероніма й використовується на позначення всіх церковнослужителів незалежно від конфесії, тому коефіцієнт уживання цієї назви є вищим. Підтвердженням сказаному, як видається, $є$ й те, що в багатьох випадках значення паремії з лексемою ксьондз тлумачиться через лексему nin, напр.: Він буде ксьондзом, як я попадею — „не буде попом ніколи, бо не хоче вчитися” (ГРНП, т. 3, с. 606); Ксьондз a лупій, то єдно — „згірдний погляд народа на попів” (ГРНП, т. 2, с. 428).

Оскільки, згідно з уявленнями селян, священики мають легкий спосіб добування засобів для прожиття, і піп, і ксьондз у пареміях омовлюються як ледарі й нероби, напр.: Попові йде i печене, i варене, $i$ з живого, $i$ з умерлого — „характеристика попівських доходів" (ГРНП, т. 2, с. 724); Богу слава, а попові шмат сала; Дурневі чудо, а попові хліб; Миша в стіжку не загине, а піп на селі; Навіщо попові гармошка, коли в нього є кадило; Ніхто не знає натуру попову: три слова скаже, а бере корову; Чудо попові, як злодієві крадений кінь та ін.; порівн.: Ксьондз каже: подай Господи, щзо високо, а щзо низько, то я си й сам озьму (ГРНП, т. 2, с. 428).

Священики як представники і православ'я, й католицизму опинилися в центрі народних прикмет, зафіксованих I. Франком, знову ж таки переважно як провісники чогось недоброго: згідно з ними побачити священика вві сні -

${ }^{11}$ Українські народні прислів'я та приказки, упоряд. В. Бобкова, Ф. Лав ров та ін.; відпов. ред. М. Т. Рильський, Київ 1955, с. 21 - далі поклик на це джерело подаємо в круглих дужках у тексті статті з використанням скорочення УНПП, після якого подаємо вказівку на конкретну сторінку. 
до ворога: Піп коли присниться, то значить до ворога (ГРНП, т. 2, с. 723); Як ти сі піп присни, то ворог під тобов риє (ГРНП, т. 2, с. 726); Як сі снит піп, то біда (ГРНП, т. 3, с. 186), а побачити священика, який переходить дорогу, - до невдачі: Як nin перейде, то буде нещістьи (ГРНП, т. 2, с. 726). Ця прикмета характерна як для української, так і для російської лінгвоспільноти, на що вказує I. Франко: Піп злий на перехід; за ним треба навідліг соломи кинути — „народне вірування. Віра в шкідливий перехід попа загально розширена. Пор. Даль I, 132” (ГРНП, т. 2, с. 726).

За народними уявленнями священики можуть навіть віщувати погоду, порівн. прикмету: Коли попи волочаться, то буде дощ (ГРНП, т. 2, с. 726). Побачити вві сні ксьондза так само погано, як і попа, ба навіть більше, адже, як фіксує І. Франко, Коли снить ся ксьондз, то се „він” (чорт) (ГРНП, т. 3, с. 180). Принагідно зазначимо, що в народних прикметах не всі релігійні концепти негативно конотовані, зокрема концепт „Церква” позначений позитивною конотацією, очевидно, тому, що українці завжди чітко розмежовували церкву, що є оселею Бога, символом неба на землі, і священиків, що не завжди належно поводяться, порівн.: Коли снить ся церков, надій ся радости (ГРНП, т. 3, с. 181). Священика критикують, як і будь-яку іншу особу. Посадова особа, напр., судді, чия діяльність так само важлива для життя селян, але часто завдає прикростей й розчарувань, також негативно конотується, порівн.: Коли сниться судія, то жде тебе якась кривда, гризота (ГРНП, т. 3, с. 181). Негативні риси священнослужителів лягли в основу стійких народних порівнянь, напр.: Лукавий, як попівське око — „злий, завидющий чоловік” (ГРНП, т. 2, с. 485). На відсутність, м'яко кажучи, пієтету в сприйнятті духовних осіб указує й те, що лексема панотець, що традиційно позначає священика, входить до складу прокляття, хай і жартівливого: Паноче, вікапали би вам очи! - „жартівливе прокляте" (ГРНП, т. 3, с. 670).

Українці критично оцінюють і діяльність духовних осіб вищого ступеня священства, зокрема владика - ,архієрей, митрополит"12 - омовлюється як жадібний (Благослови, владико, дерти з бідного лико! (УНПП, с. 25), зажерливий (У владики брюхо велике (УНПП, с. 26), нерозумний (Борода велика, а дурний владика (УНПП, с. 25)), дволикий (У владики два язики: одним бога хвалить, а другим людей дурить (УНПП, с. 25). Останню паремію в усіченому варіанті $У$ владики два язики зафіксував й І. Франко, даючи їй такий коментар: „знач. і владика може сказати раз так, а раз сяк, одурити та кривити душею” (ГРНП, т. 1, с. 345). На підкупність владик натякає паремія Владико, владико, висить над тобов лико (ГРНП, т. 1, с. 345), точніше, коментар до неї: „висмівають назву „владика” зам. епископа. Оповідають, що колись був неписьменний піп, що був висвячений за гроші, а коли епископ приїхав до нього на візитацію і велів йому правити службу божу, піп повісив над кріслом епископа кошіль з сороківцями і розпочав свою відправу отсим ,заспівом”: „Владико, владико, висит над тобов лико: потьигни і розвйижи, а що найдеш, нікому не кажи". Епископ, буцімто, зрозумів делікатний натяк, узяв гроші і лишив попа на парафіï” (ГРНП, т. 1, с. 345). За таким пастирем, як його вербалізує паремійний фонд української мови, не варто й жалкувати: Шкода невелика, щ⿻ помер владика (УНПП, с. 25).

Разом із тим, владику розглядають як певне мірило чи, так би мовити, „гарант” якості певної дії чи предмета: I владищі не годитьсі - „знач. правила при-

\footnotetext{
${ }^{12}$ Словник украӥнської мови в 11 m., ред.: акад. І. К. Білодід та ін., Київ 1978, т. 1, с. 760.
} 
личности та моральности важні не лише для простих людий, але й для найвисших” (ГРНП, т. 1, с. 345); I владиці пригодитсі — „знач. се така річ, що кожному стане в пригоді, кожному трапиться" (ГРНП, т. 1, с. 345).

У пареміях 3 ключовим словом на позначення нижчого ступеня святенництва дяк створюється негативний образ помічника священика, жадібного й ненаситного: Піп з дяком, воба вовчі горла — „оба ненаситні” (ГРНП, т. 2, с. 723); Ксьондз і дяк, воба вовчі горла — „Один і другий ніколи не насититься” (ГРНП, т. 2, с. 428).

Однак усна народна творчість вербалізує образ здебільшого бідного, найнижчого за ступенем церковнослужителя: Не кожен дячок має усе повний горщзок ${ }^{13}$; Пан піддячий любить борщ гарячий, а як голодний - то їсть і холодний, якому залишається те, від чого відмовився або чого не захотів піп: Для попа ладять, а дяки з 'їдть — „мова про празник, на який запрошено до хати попа і дяків, а піп не прийшов" (ГРНП, т. 2, с. 721). На відміну від попа, дяк концептуалізується як такий, що мало заробляє, оскільки не „дере” з людей, хоча й сумлінно виконує свої обов'язки: Піп тілько писне, а тисне, а дяк реве, а мало бере — „в богослужінню дяк співає значно більше, як священик, а проте священик одержує далеко більше доходу, як дяк” (ГРНП, т. 2, с. 723).

Однак видно, що дяка сприймають як недосвященика, недочоловіка: На безлюдді $і$ дяк чоловік (УПП, с. 356). При цьому паремії засвідчують, що він намагається впливати на мирян, напучуючи їх, а то й критикуючи за щось: Дяк, щзо будяк: хоч трошки, та вколе (УПП, с. 27). Дяк може становити для парафіян певну загрозу і його треба побоюватися: Перо страшне не в гусака, $a$ вже тоді, як у дяка (УПП, с. 27). Думаємо, що це пов’язано з діяльністю дяка як сільського секретаря, де помилка в укладанні документів могла спричинитися в подальшому до неприємностей у селянина.

Заслуговує на увагу й мовний образ nonadi, що вербалізується в низці паремій зі смислом „несамостійна особистість, чий добробут цілком залежить від життя й діяльності чоловіка-попа", напр.: Доти попадя княгиня, поки піп не загине (УПП, с. 27); За попом дзвонять, а попадю з села гонять (ГРНП, т. 2, с. 721); Поки попа, поти попадя, як не стане попа, то пропадя — „сумна доля попаді по смерти попа" (ГРНП, т. 2, с. 724); Піп умирає, попадя ся вибирає „Попадя по смерти попа мусить покидати засиджену доси теплу хату” (ГРНП, т. 2, с. 724). Але, разом із тим, вона має неабиякий вплив на сільське життя, оскільки може командувати, керувати діями свого чоловіка й селян: Коли б нашій попаді та попова борода, давно б благочинною була (УПП, с. 358). У пареміях відображені такі риси характеру попаді, як нестриманість: Коли попадю сказило, то не поможе й кадило (УПП, с. 358), жадібність, ненаситність: Або я попадя, аби я курку з '̈̈ла? (ГРНП, т. 2, с. 764). За народним уявленнями, попадя заможна, за життя чоловіка вона не знає скрути: Пiду до nonadi, mo npuнесу тобі й собi - „говорить кума до куми, надіючись, що в попаді добуде чогось такого, чого у них обох нема" (ГРНП, т. 2, с. 764).

На іронічне сприйняття попаді в народі вказує й те, що про неї згадують у багатьох прокльонах (Попадя би тя з '̈ля - „кленуть курці” (ГРНП, т. 2, с. 764), жартівливих приказках-дражнилках (Попадя, лопадя горох молотила, линдик покришила, бураки зарєдила — „жартівлива приказка про попадю,

${ }^{13}$ Украӥнські прислів'я та приказки, упорядкування С. В. Мишанича та М. М. Пазяка, Київ 1984, с. 357- далі поклик на це джерело подаємо в круглих дужках у тексті статті з використанням скорочення УПП, після якого подаємо вказівку на конкретну сторінку. 
значіне неясне" (ГРНП, т. 2, с. 764), пісеньках (У нашої попаді три кусати на зад $i$ - „жартівливий вислов, а властиво початок пісеньки, якої дальші два рядки звучать так: „Добре з нею гуляти, є сі за що тримати” (ГРНП, т. 2, с. 764), пародіях (Вірую, зарізав піп кобилу сірую, а попаде варила, тай фостом сьи удавила — „народна пародія початку молитви” (ГРНП, т. 3, с. 529).

Не пройшов повз увагу селян й образ ченця, що теж вербалізуєтся цілком критично, оскільки в пареміях іронічно вказується на малоосвіченість монахів: Був ту мних, що мав богато книг, а не знав, щуо в них - „Про неграмотного чоловіка" (ГРНП, т.2, с. 542), їх тілесну й духовну гріховність: Чорний клобук святості не придас; Як рибі без води, так ченџю без жони; Що козаку видиться, те монаху сниться (УПП, с. 359); Чернець святиі розгортає, а на молодииь поглядає; Чениі і бога в монастирях продають; Чернецька злоба до гро-

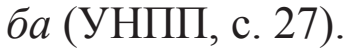

Образ ігумена теж омовлюється іронічно з указівкою на те, що попри високий сан окремі представники монастирської верхівки не є зразком дотримання чеснот, порівн.: Ігуменові як ігуменові, а ченцеві зась — „ігуменові вільно дещо таке, на що чернець не може позволити. Іронізують прим. над ігуменом п'яницею або чужоложником" (ГРНП, т. 2, с. 290); Коли ігумен за чарку, то братія за кварту - „досить старшому дати злий приклад, то вже його підвладні підуть далі" (ГРНП, т. 2, с. 290).

До складу українських паремій уходять назви ченців різних орденів, зокрема єзуїтського. Такі вислови позначені посиленою експресією, очевидно, тому, що в українській лінгвокультурі лексема єзуїm, окрім свого прямого номінативного значення „1. Член католицького чернечого ордену „Товариство Ісуса", що $є$ найреакційнішою й найвойовничішою організацією католицької церви", має ще й переносне значення з актуалізованими негативними семами „підлість”, „підступність”, „дволикість”; „2. Про підступну, підлу, лицемірну людину" ", порівн.: Він Єзуітом підшитий — „Хитрий, дволичний чоловік” (ГРНП, т. 2, с. 124); О, то хитрий єзуїт - „Облесний, інтригант” (ГРНП, т. 2, с. 124). По суті, другий лексико-семантичний варіант слова єзуїm у наведених пареміях уживається як експресив, спроможний створювати експресивний простір тексту, крім того, в його складі $\epsilon$ емоційно-оцінний інгредієнт, що репрезентує негативну оцінку. Загальновідомо, що більшість слів в українській мові 3 емоційно-оцінним інгредієнтом мають негативну семантику. Експресивність подібних лексем В. Чабаненко умотивовано пояснює тим, що ,людина в своїй активній боротьбі з усім потворним, злим, ворожим, неприйнятним для іiі життєвих ідеалів постійно шукає все нових і нових засобів відповідної мовленнєвої експресії, а відтак постійно збільшує кількість цих засобів" $" 15$.

Попри переважно негативну оцінку образу священнослужителя серед українських паремій трапляються й ті, що в них духовні особи характеризуються як освічені, чесні й порядні люди. Так, згідно з паремією Бидла служать до плуга і до воза: ти собі тото бери добре до носа, же мало знати не єсть доста, аще хочеш стати чесно до крилоса ${ }^{16}$, щоб служити в церкві, тобто бути священиком, треба добре вчитися. Очевидно, в такому разі відбувається актуалізація сем „освічений”, „розумний”. Подібне простежуємо й у паремії

${ }^{14}$ Словник украӥнської мови ..., т. 2, с. 497.

15 В. А. Ч абаненко, зазн. джерело, с. 151.

${ }^{16}$ I. П ан ь ке в и ч, Збірка народних південно-карпатських приповідок Івана Югасевича 3 p. 1809, [в:] „Науковий збірник Товариства „Просвіта” в Ужгороді”, Ужгород 1929, т. VI, с. 10. 
Не каждий, штося учить, може бути священик, пан або чернець, але може бути чесний чоловік, у изеркві добрий півець, чтецьв ${ }^{17}$. За свідченням I. Франка, вираз Піп на тото $і$ є, щзоб прахтики розповідав характеризує священика як освічену розумну особистість, що може дати іншому слушну пораду: „Він має все вищу освіту й може сказати щось про ширший світ" (ГРНП, т. 2, с. 723). Авторські спостереження щодо позитивної, хоч і не частої, конотації образу священнослужителя збігаються 3 думкою Т. Свердан, яка, здійснюючи аналіз паремій, зібраних I. Югасевичем, зазначає: „Несподіваною є впевненість у тому, що На корчмі не глядай попа, але хлопа - зазвичай в українських прислів'ях відображені не зовсім доброзичливі відгуки про попів, зрештою, й саме слово nin в українській мові набуло зневажливих конотацій, на відміну від позитивно конотованих слів священик, отещ̧ь, духівник і под." $"$.

Отже, паремійний фонд української мови, зафіксований у збірках, демонструє тяжіння до вербалізації негативного образу священнослужителя незалежно від його сану й конфесійної приналежності. Він концептуалізується як жадібний, нещирий, чистолюбивий й серебролюбивий, байдужий до людського горя тощо. Іронічна оцінка як приходського священика і його дружини попаді, так і монаха, очевидно, пояснюється тим, що в народній свідомості їх сприймають насамперед не як посередників між Богом і мирянами, а як власне грішних людей.

У подальших розвідках актуальним буде дослідження специфіки вербалізації в українських пареміях інших концептів, що входять до концептосфери „Релігія”.

${ }^{17}$ Там само.

${ }^{18}$ Т. С в ердан, зазн. джерело, с. 125. 